Research article / Научная статья

\title{
Political Implications of Orthodox Identity: An Example of the World Russian People's Council
}

\author{
N.D. Shikher \\ The Russian Presidential Academy of National Economy and Public Administration, Moscow, \\ Russian Federation \\ Office of the High Commissioner for Human Rights in the Russian Federation, Moscow, \\ Russian Federation
}

\begin{abstract}
The article examines the conceptual ideas of the World Russian People's Council, acting under the auspices of the Russian Orthodox Church, regarding the implementation of the right to freedom of conscience and the status of religious associations in Russia. Furthermore, the speeches of heads of the states at the Councils were studied for their attitude to the ideological content of the activities of this organization. On the basis of the data obtained, the author attempts to find a correlation between the proposals voiced at the Councils on changing certain aspects in the religious sphere and the reforms of the Russian legislation on freedom of conscience. As a result of this study, a striking coincidence was revealed between the two factors mentioned: the provisions discussed at the Councils, as a rule, after some time were reflected in Russian normative legal acts. Not having sufficient grounds for declaring an unambiguous causal relationship between conciliar ideas and legislative reform, one can, in any case, assume a significant impact of the activities of the World Russian People's Council on the state policy in implementation of the right to freedom of conscience in modern Russia.
\end{abstract}

Keywords: World Russian People's Council, Orthodoxy, the right to freedom of conscience, religion-state relations, religion and law

For citation: Shikher, N.D. (2021). Political implications of Orthodox identity: An example of the World Russian People's Council. RUDN Journal of Political Science, 23(4), 600-613. DOI: 10.22363/2313-1438-2021-23-4-600-613

\section{Политические импликации православной идентичности: пример Всемирного русского народного Собора}

\author{
Н.Д. Шихер
}

Российская академия народного хозяйства и государственной службы при Президенте Российской Федерации, Москва, Российская Федерация

Аппарат Уполномоченного по правам человека в Российской Федерации, Москва, Российская Федерация

Аннотация. В статье исследованы концептуальные идеи Всемирного русского народного Собора, действующего под эгидой Русской Православной Церкви, относительно

(C) Shikher N.D., 2021

(7) This work is licensed under a Creative Commons Attribution 4.0 International License https://creativecommons.org/licenses/by/4.0/ 
реализации права на свободу совести и положения религиозных объединений в России. Также изучены выступления на Соборах первых лиц государства на предмет их отношения к идейному содержанию деятельности данной организации. На основе полученных данных автором предпринята попытка соотнести озвученные на Соборах предложения по изменению отдельных аспектов в религиозной сфере с реформами российского законодательства о свободе совести. В результате данного исследования выявлено поразительное совпадение между двумя указанными факторами: обсуждаемые на Соборах положения, как правило, спустя некоторое время находили отражение в российских нормативно-правовых актах. Не имея достаточных оснований заявлять об однозначной причинно-следственной связи между соборными идеями и реформированием законодательства, можно, во всяком случае, вести речь о значительном влиянии деятельности Всемирного русского народного Собора на политику государства в области реализации права на свободу совести в современной России.

Ключевые слова: Всемирный русский народный Собор, православие, право на свободу совести, государственно-конфессиональные отношения, религия и право

Для цитирования: Shikher N.D. Political implications of Orthodox identity: An example of the World Russian People's Council // Вестник Российского университета дружбы народов. Серия: Политология. 2021. T. 23. № 4. С. 600-613. DOI: 10.22363/2313-1438-2021-23-4-600-613

\section{Introduction}

In recent years, the topic of church-state interaction and Orthodox identity has become increasingly relevant. The growing role of the Russian Orthodox Church in the socio-political space is causing lively discussions not only in the media space, but also in the scientific community. Among recent studies in this area works by Bogachev M.I. [Bogachev, Sorvin 2020:331-361; Bogachev 2018:224238], Meshcheryakova A.F. [Meshcheryakova 2020:59-79], Mchedlova M.M. [Mchedlova 2020:59-79; Mchedlova 2020:13-35; Mchedlova, Kazarinova 2020:13-35; Mchedlova 2020:7-21], Pinkevich V.K. [Pinkevich 2020:647-663], Shchipkov A.V. [Shchipkov 2018; Shchipkov 2021] are of a great interest. The researchers emphasize the special importance of the Orthodox factor in the post-secular political space. At the same time the authors' assessments of Church-State policy vary from approval (Meshcheryakova A.F., Shchipkov A.V.) to criticism (Bogachev M.I., Pinkevich V.K.). Through the prism of the activities of the World Russian People's Council this issue is considered by Ierusalimskiy Yu.Yu. and Rudakov A.B [Ierusalimskiy, Rudakov 2019:437-445; Rudakov 2020:19-22; Ierusalimskiy, Rudakov 2021:117-124].

The research aims at finding the relationship between the ideological concepts of the World Russian People's Council and Russian legal novels. The research methodology consists of the content analysis of the speeches of the participants of the Council and the final documents of the Council, as well as of the comparative analysis of the existing normative legal acts.

\section{World Russian People's Council as the articulator of the Orthodox identity politics}

In modern Russia the opinion of the Russian Orthodox Church is actively involved in the process of substantiation of the goals and objectives of social 
development from the ideological point of view. The state supports such provisions as traditional values, patriotism, a special "Russian way", "State-Church symphony" and others. Since 1993 the World Russian People's Council (hereinafter WRPC or the Council), functioning under the auspices of the Russian Orthodox Church, has become one of the main platforms where these concepts have been born through annual discussions. WRPC is an international public organization, which aims at participating in the development of strategies for the development of the state on the basis of a dialogue between the authorities, church and society. Despite being only a platform for discussing pressing social and political problems on the threshold of its formation, currently the Council can rightfully be called one of the most important actors in modern politics, influencing the key areas of social development. Although formally the WRPC is not a part of the Russian Orthodox Church structure and is not associated with the public sphere, Patriarch Kirill of Moscow and All Russia acts as the chairman and constant inspirer of the Council. Furthermore, representatives of the top political elite, including the head of state, are permanent participants. In other words, the Council operates under the auspices of the Church and has the support of the state, which significantly increases its political weight and creates a solid authority in the religion-state environment.

As a result of each Council materials aimed at "forming the personal and national self-consciousness of Russians" are published. In addition to representatives of traditional denominations, top officials of the state, politicians and state officials of all levels regularly take an active part in the activities of the Councils. This article attempts to analyze the ideas voiced at the WRPC regarding a meaningful understanding of the right to freedom of conscience, the legal status of religious associations and the development of Russian religion-state relations, and track their further implementation on the governmental level.

As already mentioned, since the main proponent of the Council is the Russian Orthodox Church, and its chairman is His Holiness the Patriarch, it is natural that at each WRPC, depending on its subject matter, the participants voice their views on the role of Orthodoxy and the Russian Orthodox Church in a particular sphere of social life. This may indicate either a desire for unanimity on the part of the organizers of the Council when selecting participants, or a general trend of loyalty to Orthodoxy on the part of the ruling elite and the public. The second option seems more likely since over the past three decades the staff of the top government positions has changed several times, however, all of them invariably remaining a part of the Council. As a general refrain of most speeches, statements are made about the importance of preserving traditional moral values and the potential of the Russian Orthodox Church in the consolidation of all Russian people and all Orthodox people ${ }^{2}$. Orthodoxy is proposed to be recognized as the one playing a historical and consolidating role in the life of the people. Social problems are

\footnotetext{
${ }^{1}$ Council Word VIII WRPC. The official website of the World Russian People's Council. URL: https:/vrns.ru/documents/sobornoe-slovo-viii-vsemirnogo-russkogo-narodnogo-sobora/ (accessed: 05.05.2021).
}

${ }^{2}$ Ibid. 
associated with the moral impoverishment of the human person, the cause of which is the loss of the original folk spirituality based on Orthodoxy ${ }^{3}$. In the Final Document III of the WRPC it is determined that the spiritually renewed Russian nation must "recreate the ideal of Holy Russia, that is, to re-base our life on the principles of the truth of God, love, peace, harmony, creation and realism"4 ${ }^{\text {. In other }}$ words, Orthodoxy is assigned a special creative and consolidating role in society and the state.

\section{Participation of the political elite in Council activities}

It is important for our research that this concept is fully supported by the authorities. The very fact of the annual participation of the leaders of the state in the Councils indicates the sympathy of the authorities for the activities of this public organization, and the analysis of their speeches only confirms this hypothesis.

Thus, the President of Russia has repeatedly expressed the idea of the need for "genuine collaboration with the Russian Orthodox Church". The Chairman of the Federation Council of the Federal Assembly of the Russian Federation noted that "Russian society places special hopes on the activities of the revived Russian Orthodox Church". In the speech of the Chairman of the State Duma of the Federal Assembly of the Russian Federation it is stated that "after many years of vacillation and confusion Russia has only one saving path, that is to God, to light and rebirth"7. According to the Chief of Staff of the Presidential Administration of Russia, "Orthodoxy has become not only a spiritual bond for the multi-million Russian society, but it also brings many Slavic people together, unites our compatriots and everyone who feels close to this spiritual and cultural space"8.

The President of the Constitutional Court of the Russian Federation called the threshold of the 21 st century "a threshold of the church - of great Russia, gathered together, renewed and prosperous, being able to find itself and consequently to open

\footnotetext{
${ }^{3}$ Appeal of the II WRPC. The official website of the World Russian People's Council. URL: https://vrns.ru/documents/obrashcheniya-ii-vsemirnogo-russkogo-sobora/ (accessed: 28.04.2021).

${ }^{4}$ III WRPC documents. The official website of the World Russian People's Council. URL: https://vrns.ru/ documents/dokumenty-iii-vsemirnogo-russkogo-narodnogo-sobora/ (accessed: 28.04.2021).

${ }^{5}$ Welcoming speech of the President of Russia Putin V.V. at XXIII WRPC. The official website of the World Russian People's Council. URL: https://vrns.ru/documents/privetstvie-prezidenta-rf-v-vputina/ (accessed: 16.05.2021).

${ }^{6}$ Greetings from the Chairman of the Federation Council of the Federal Assembly of the Russian Federation III WRPC. The official website of the World Russian People's Council. URL: https://vrns.ru/documents/privetstvie-shumeyko-v-f-predsedatel-soveta-federatsii-federalnogosobraniya-rossiyskoy-federatsii/ (accessed: 28.04.2021).

${ }^{7}$ Speech by the Chairman of the State Duma of the Federal Assembly of the Russian Federation G.N. Seleznev on V WRPC. The official website of the World Russian People's Council. URL: https://vrns.ru/documents/stenogramma-pervogo-dnya-zasedaniya-v-vrns-rossiya-nakanune-2000letiya-khristianstva-vera-narod-vla/ (accessed: 05.05.2021).

${ }^{8}$ Speech by Sergey Ivanov, Chief of Staff of the Presidential Executive Office at the XVI WRPC. The official website of the World Russian People's Council. URL: https:/vrns.ru/documents/ ivanov-sergey-borisovich-rukovoditel-administratsii-prezidenta-rossiyskoy-federatsii/ (accessed: 13.05.2021).
} 
up to the world"9. The Minister of Foreign Affairs of the Russian Federation noted that "our adherence to Christianity, which we adopted 1000 years ago, is currently being tested. "Man shall not live by bread alone", "to lay down your life for your friends" and other commandments have never been abstract concepts for us - they determined the very content of our life, our deeds" $"$. The Chairman of the Accounts Chamber of the Russian Federation expressed the position that "it is the Church that is currently becoming one of the key elements of the formation of the spiritual security of the state, the moral potential of society and, most importantly, of the upbringing and enlightenment of young people"11.

The speeches of some leaders of political parties contain various references to support of Orthodoxy. For example, the leader of the Liberal Democratic Party said that being a believer and being baptized, he "was never a member of any party that would destroy churches, infringing the rights of the Russian Orthodox Church in any way"12. The leader of the "Yabloko" party referred to the fact that "with people who do not believe in the future and with people who do not believe in God, it is impossible to conduct any effective reforms ... Humanism and Christianity, humanism and faith are the future, we are convinced of this, being a part of liberal democracy movement"13.

This brief overview of some of the speeches of the representatives of the authorities allows us to conclude that the ideological content of the WRPC activity has been invariably sincerely supported and responded by the authorities over almost three decades. Several key points can be identified that indicate the vector of state policy in regard to religious organizations. Firstly, the willingness of the political elite to take an active part in the Council, which openly positions itself as an Orthodox public organization supporting spiritual and moral development of the society. Secondly, public statements by the top officials of the state about the exclusiveness of Orthodoxy and the Russian Orthodox Church for the Russian state and the society. Thirdly, public self-identification of the authorities' representatives with Orthodoxy. These facts show a rapid tendency of the state towards

\footnotetext{
${ }^{9}$ Speech by the Chairman of the Constitutional Court of the Russian Federation V.D. Zorkin on III WRPC. The official website of the World Russian People's Council. URL: https://vrns.ru/ documents/stenogramma-iii-vrns/ (accessed: 30.04.2021).

${ }^{10}$ Speech by the Minister of Foreign Affairs of the Russian Federation S.V. Lavrov at the X WRPC. The official website of the World Russian People's Council. URL: https:/vrns.ru/documents/ vystuplenie-ministra-inostrannykh-del-rossii-s-v-lavrova-na-X-vrns/ (accessed: 06.05.2021).

${ }^{11}$ Speech by the Chairman of the Accounts Chamber of the Russian Federation S.V. Stepashin at the XIV WRPC. The official website of the World Russian People's Council. URL: https://vrns.ru/ documents/privetstvie-predsedatelya-schetnoy-palaty-rossiyskoy-federatsii-predsedatelya-imperatorskogopravosl/ (accessed: 06.05.2021).

${ }^{12}$ Speech by the Head of the Liberal Democratic Party of Russia Zhirinovsky V.F. at the III WRPC. The official website of the World Russian People's Council. URL: https://vrns.ru/documents/ stenogramma-iii-vrns/ (accessed: 30.04.2021).

${ }^{13}$ Speech by the leader of the "Yabloko" party G. Yavlinsky on VI WRPC. The official website of the World Russian People's Council. URL: https:/vrns.ru/documents/plenarnye-zasedaniya-vkhrame-khrista-spasitelya/ (accessed: 05.05.2021).
} 
rapprochement with the Russian Orthodox Church and the exclusiveness of the Orthodox component in the state policy in regard to religion.

However, in our opinion, the most important fact in relations between the public authorities and the WRPC is the state's readiness to implement the Council's initiatives based on Orthodox values in the field of the right to freedom of conscience and the activities of religious associations in Russia.

\section{Modern Russian legislation on the right to freedom of conscience}

Before proceeding to the immediate consideration of the ideological concepts of WRPC, subsequently implemented at the legislative level or in law enforcement practice, we will briefly consider the modern normative regulation of the right to freedom of conscience in Russia.

The current Russian Constitution enshrines the principle of secularism and separation of religious associations from the state (Article 14) and also guarantees everyone the right to freedom of conscience, freedom of religion, including the right to profess individually or jointly with others any religion or not to profess any religion (Article 28) ${ }^{14}$. At the same time, in 2020, Article 67.1 of the Constitution was amended and now indicate that the faith in God was transmitted to Russian people by their ancestors ${ }^{15}$. The Constitutional Court of the Russian Federation clarified that these changes do not mean "a rejection of the secular nature of the Russian state ... and freedom of conscience, since in their formulation they are not associated with confessional affiliation"16. However, in conjunction with the preamble to the Federal Law "On freedom of conscience and on religious associations" $"$, which assign the Orthodoxy a special role in the history of Russia and in the formation and development of its spirituality and culture, and Christianity, Islam, Judaism and Buddhism constitute an integral part of the historical heritage of the people of Russia, it is obvious that traditional religions and, first of all, Orthodoxy, seem to be of some political and legal preference. Consequently, religion-state relations based on the current legislation are developing in a given direction, but at the same time, the right to freedom of conscience, as the right of personal religious choice, remains under inviolable

\footnotetext{
${ }^{14}$ Constitution of the Russian Federation dated 12.12.93. Collected Legislation of the Russian Federation, 08/04/2014, N 31, Art. 4398.

${ }^{15}$ Constitution of the Russian Federation dated 12.12.93. Rossiyskaya gazeta. 04.07.2020. No. 144.

${ }^{16}$ Clause 3 of the Conclusion of the Constitutional Court of the Russian Federation dated March 16, 2020 No. 1-3 "On the compliance with the provisions of Chapters 1, 2 and 9 of the Constitution of the Russian Federation of the provisions of the Law of the Russian Federation on the amendment to the Constitution of the Russian Federation." On improving the regulation of certain issues of organization and functioning of public authorities", as well as on the compliance with the Constitution of the Russian Federation of the procedure for the entry into force of Article 1 of this Law in connection with the request of the President of the Russian Federation". Rossiyskaya gazeta. 17.03.2020. No. 56 (8110).

${ }^{17}$ Federal Law No. 125-FZ of September 26, 1997 "On Freedom of Conscience and on Religious Associations." Collected Legislation of the Russian Federation, 09/29/1997, N 39, Art. 4465.
} 
constitutional protection. Thus, Russian legal regulation on the relationship between the state and religious organizations contributes to the manifestation of political favoring of Orthodoxy on the part of the state.

\section{Reception of council concepts by the Russian legislator}

Having an idea of the Russian legislation on the right to freedom of conscience, we proceed to studying of those of its elements that correlate with the ideas developed under the WRPC.

1. One of the subjects of discussion of the very first WRPC in 1993 was the issue of limiting the activities of destructive religious associations. Thus, in the resolution of the thematic group "State Development of Russia" I of the WRPC underlines the need to limit missionary activity of foreign citizens: "only our citizens can preach in our country. Foreign citizens can carry out missionary activities only by the invitation of the heads of traditional confessions. It is necessary to introduce a clearer legal regulation of the organization and activities of various sects on the territory of our country"18. The resolution of the thematic group "Ways and goals of the spiritual revival of Russia" I of the WRPC states that freedom of conscience is "violated by the actions of some missionaries, who use their material advantages to impose their convictions on Russian people" 19 . Moreover, foreign organizations, which are of dubious popularity in their homeland, open their branches in Russia. The discussion on this topic continued at the VI WRPC in 2001. The Governor of the Kaliningrad Region Yegorov V.G. named several religious organizations "of concern: Mormons, Jehovah's Witnesses, Church of Scientology"20. Chairman of the State Duma Committee for Interaction with Public and Religious Organizations Zorkaltsev V.I. named the weakness of ensuring spiritual security as one of the most important problems in Russia, which, in his opinion, consists of opposing extremism, supporting the legal rights of traditional confessions, controlling the spread of totalitarian sects and pseudoreligious organizations such as Jehovah's Witnesses ${ }^{21}$.

Years later all these ideas have been embodied in Russian legislation and jurisprudence. The law adopted in 2016, which received the code name "Ozerov-

\footnotetext{
${ }^{18}$ Resolution of the thematic group "State development of Russia" I WRPC. The official website of the World Russian People's Council. URL: https://vrns.ru/documents/rezolyutsiya-tematicheskoygruppy-gosudarstvennoe-razvitie-rossii/ (accessed: 28.04.2021).

${ }^{19}$ Resolution of the thematic group "Ways and goals of the spiritual revival of Russia" I WRPC. The official website of the World Russian People's Council. URL: https://vrns.ru/documents/ rezolyutsiya-tematicheskoy-gruppy-puti-i-tseli-dukhovnogo-vozrozhdeniya-rossii/ (accessed: 28.04.2021).

${ }^{20}$ Speech by the Governor of the Kaliningrad Region V.G. Yegorov at the meeting of the section "Church. Nation. State" VI WRPC. The official website of the World Russian People's Council. URL: https://vrns.ru/documents/sektsiya-tserkov-natsiya-gosudarstvo/ (accessed: 05.05.2021).

${ }^{21}$ Speech by the Chairman of the State Duma Committee on Interaction with Public and Religious Organizations V.I. Zorkaltsev The official website of the World Russian People's Council. URL: https://vrns.ru/documents/sektsiya-tserkov-natsiya-gosudarstvo/ (accessed: 05.05.2021).
} 
Yarovaya package",22, introduced a number of restrictions for local religious organizations and religious groupsю. In particular, the law concerned inviting foreign citizens to engage in professional religious activities, including preaching. If until then various religious groups were actively preaching in Russia, now this activity has become permitted only for foreigners invited by a religious organization that has been operating on Russian territory for more than 10 years. Therefore, the number of non-traditional religious associations was significantly reduced. In 2016-2017 a number of trials were held against the Church of Scientology ${ }^{23}$, and one of the most numerous religious organizations, Jehovah's Witnesses, was finally liquidated ${ }^{24}$.

2. At the III WRPC, held in 1995, the topic of the return of property removed during the Soviet era back to religious organizations was raised ${ }^{25}$. This issue was also discussed at the X WRPC in 2006. Based on the results of the discussion, a resolution was adopted in support of the transfer of buildings in the Ryazan Kremlin to the $\mathrm{Church}^{26}$.

The state supported this idea in 2010, when a large-scale campaign was launched to return the ownership or use of religious organizations, mainly the Russian Orthodox Church, immovable and movable property nationalized by the Soviet government ${ }^{27}$.

3. At the VIII WRPC in 2004 a resolution on spiritual and religious education in Russia was adopted, which claimed "the vital need for Russia to remove all bureaucratic obstacles for teaching the Fundamentals of Orthodox culture in secondary schools while preserving the principle of voluntariness" ${ }^{28}$. In the same resolution the legislator raised the issue of state certification and accreditation of

\footnotetext{
${ }^{22}$ Federal Law of 06.07.2016 No. 374-FZ “On Amendments to the Federal Law" On Countering Terrorism "and certain legislative acts of the Russian Federation in terms of establishing additional measures to counter terrorism and ensure public safety". Collected Legislation of the Russian Federation dated July 11, 2016 No. 28 Art. 4558.

${ }^{23}$ See, for example: the Supreme Court of the Russian Federation recognized the liquidation of the Church of Scientology as legal. Official site of the Russian newspaper. URL: https://rg.ru/2016/06/ 29/verhovnyj-sud-rf-priznal-zakonnoj-likvidaciiu-saentologicheskoj-cerkvi.html (accessed: 05.25.2021).

${ }^{24}$ Decision of the Supreme Court of the Russian Federation of 20.04.2017 N AKPI17-238; Appellate ruling of the Supreme Court of the Russian Federation of July 17, 2017 N APL17-216. Official site of the company "Consultant Plus". URL: http://www.consultant.ru/cons/cgi/online.cgi?req=doc; base $=$ ARB002; $=501863 \# 02535797431465554$ (accessed: 02.08.2018).

${ }^{25}$ III WRPC documents. The official website of the World Russian People's Council. URL: https://vrns.ru/documents/dokumenty-iii-vsemirnogo-russkogo-narodnogo-sobora/ (accessed: 28.04.2021).

${ }^{26}$ Resolution X WRPC in support of the transfer of buildings in the Ryazan Kremlin to the Church. The official website of the World Russian People's Council. URL: https://vrns.ru/documents/ rezolyutsiya-X-vrns-v-podderzhku-peredachi-tserkvi-zdaniy-v-ryazanskom-kremle/ (accessed: 05.06.2021).

${ }^{27}$ Federal Law No. 327 FZ of 30.11.10 "On the Transfer of State or Municipal Property of Religious Purpose to Religious Organizations". Collected Legislation of the Russian Federation, 06.12.2010, N 49, Art. 6423.

${ }^{28}$ Resolution VIII of the WRPC on spiritual and religious education in Russia. The official website of the World Russian People's Council. URL: https://vrns.ru/documents/rezolyutsiya-viii-vrns-odukhovnom-i-religioznom-obrazovanii-v-rossii/ (accessed: 05.05.2021).
} 
religious educational institutions. By the resolution "On the development of the domestic system of religious education and science" XI WRPC in 2007 it was decided to request the Government of Russia to include the specialty "theology" in the list of scientific specialties of the Higher Attestation Commission, to initiate amendments to the legislation on the provision of religious educational institutions the rights of state accreditation and recognition of their diplomas and to include the subject of teaching the basics of Orthodox culture and ethics in the federal educational standard ${ }^{29}$.

All these proposals were soon implemented: the subject "Fundamentals of Orthodox Culture" was added to the school curriculum in 2006 (later transformed into "Fundamentals of religious cultures and secular ethics") ${ }^{30}$, since 2008 the religious high schools were given the right to issue state diplomas ${ }^{31}$, and in 2015 , "theology" was included in the list of scientific specialties ${ }^{32}$.

4. The "Declaration of Human Rights and Dignity" adopted at the 10th WRPC in 2006 states that it is unacceptable to insult religious and national feelings, revered shrines $^{33}$.

In 2013, amendments were made to the administrative and criminal legislation in order to prohibit insulting the feelings of believers ${ }^{34}$. According to Article 5.26 of the Code of Administrative Offenses of the Russian Federation, a number of fines of up to one million rubles are provided for obstructing the exercise of the right to freedom of conscience and freedom of religion, deliberate public desecration of religious objects, etc. According to Article 148 of the Criminal Code of the Russian

${ }^{29}$ Resolution "On the development of the national system of religious education and science" XI WRPC. The official website of the World Russian People's Council. URL: https://vrns.ru/ documents/rezolyutsiya-o-razvitii-otechestvennoy-sistemy-religioznogo-obrazovaniya-i-nauki/ (accessed: 05.06.2021).

${ }^{30}$ See, for example: "Fundamentals of Orthodox Culture" is introduced as a compulsory course in four Russian regions. Official site of the Moscow Patriarchate. URL: http://www.patriarchia.ru/ $\mathrm{db} / \mathrm{text} / 137341 . \mathrm{html}$ (accessed: 05.19.2021); Order of the Ministry of Education and Science of 01.02.2012 No. 74 "On Amendments to the Federal Basic Curriculum and Model Curricula for Educational Institutions of the Russian Federation Implementing General Education Programs". "Bulletin of Education of Russia", April 2012, No. 7.

${ }^{31}$ Federal Law of February 28, 2008 N 14-FZ "On Amendments to Certain Legislative Acts of the Russian Federation Regarding Licensing and Accreditation of Professional Religious Education Institutions (Spiritual Educational Institutions)". Collected Legislation of the Russian Federation dated March 3, 2008 N 9, Art. 813.

${ }^{32}$ See, for example: "Theology was officially recognized as a scientific specialty." Official site of Russian newspaper. URL: https://rg.ru/2015/10/13/teologiya.html (accessed: 05.19.2021); Minutes of the Presidium of the Higher Attestation Commission under the Ministry of Education and Science of the Russian Federation No. 24 dated September 25, 2015, recommendation No. 24/555.

${ }^{33}$ Declaration of Human Rights and Dignity, adopted at the X WRPC. The official website of the World Russian People's Council. URL: https://vrns.ru/documents/deklaratsiya-o-pravakh-idostoinstve-cheloveka/ (accessed: 05.06.2021).

${ }^{34}$ Federal Law of June 29, 2013 N 136-FZ "On Amendments to Article 148 of the Criminal Code of the Russian Federation and Certain Legislative Acts of the Russian Federation in order to counteract insult to the religious beliefs and feelings of citizens." "Collection of legislation of the Russian Federation", 01.07.2013, N 26, art. 3209. 
Federation, for public actions, which express clear disrespect for society and committed in order to offend the religious feelings of believers, one face a penalty of up to three years in prison.

5. At different WRPC the moral ideals that consolidate Russian society were discussed: "mutual respect, love for the Motherland and respect for family values, national cultural and spiritual traditions"35. The need to amend the Russian Constitution on the patriotic education of citizens ${ }^{36}$ and on the protection of historical truth was also considered ${ }^{37}$.

All these ideas are to a certain extent reflected in Article 67.1 of the Constitution of the Russian Federation, according of parts 3 and 4 of which "The Russian Federation honors the memory of the defenders of the Fatherland, provides protection of historical truth. Diminishing the significance of the heroic deed of the people in the defense of the Fatherland is not allowed. Children are the most important priority of Russian state policy. The state creates proper conditions to the extensive spiritual, moral, intellectual and physical development of children, as well as for fostering patriotism, citizenship and respect for the elderly. The state ensures the priority of family education and assumes the responsibilities of parents in relation to children left without care" ${ }^{, 38}$. Interestingly, in the initial version of the above-mentioned constitutional provisions, children were called "the most important property of Russia" 39 , which correlates with the title of the program document of the XIII WRPC, which is "Future generations are the national heritage of Russia" $" 40$.

The study made it possible to see a clear parallel between the conceptual provisions proposed by the WRPC and the subsequent reform of the legislation on freedom of conscience. For clarity of the indicated conclusion, the corresponding comparative table is given below:

\footnotetext{
${ }^{35}$ Greetings from the President of Russia Dmitry Medvedev to the participants of the XV WRPC. The official website of the World Russian People's Council. URL: https://vrns.ru/documents/ privetstvie-prezidenta-rossii-d-a-medvedeva-uchastnikam-xv-vsemirnogo-russkogo-narodnogo-sobora/ (accessed: 11.05.2021).

${ }^{36}$ Resolution of the section "History of Russia - the history of love of the Fatherland. Problems of patriotism in modern Russia" XVI WRPC. The official website of the World Russian People's Council. URL: https://vrns.ru/documents/rezolyutsiya-sektsii-istoriya-rossii-istoriya-otchiznolyubiyaproblemy-patriotizma-v-sovremennoy-ros/ (accessed: 11.05.2021).

${ }^{37}$ Section "Historical truth of Victory in the Great Patriotic War" IX WRPC. The official website of the World Russian People's Council. URL: https://vrns.ru/documents/sektsiya-istoricheskayapravda-pobedy-v-velikoy-otechestvennoy-voyne/ (accessed: 19.05.2021).

${ }^{38}$ Constitution of the Russian Federation dated 12.12.93. Rossiyskaya gazeta. 04.07.2020. No. 144.

${ }^{39}$ See, for example: "The Committee approved an amendment to the Constitution about children as the property of Russia". Official site of the Russian newspaper. URL: https://rg.ru/2020/03/03/ komitet-odobril-popravku-v-konstituciiu-o-detiah-kak-o-dostoianii-rossii.html (accessed: 19.05.2021).

${ }^{40}$ Program document XIII WRPC "Future generations - the national treasure of Russia." The official website of the World Russian People's Council. URL: https:/vrns.ru/documents/programmnyydokument-xiii-vsemirnogo-russkogo-narodnogo-sobora-budushchie-pokoleniya-natsionalnoe-do/ (accessed: 05.06.2021).
} 
Summary comparison of ideas developed by WRPC and Russian legal acts

\begin{tabular}{|c|c|c|c|c|}
\hline No. & $\begin{array}{c}\text { Ideas developed } \\
\text { within } \\
\text { the framework } \\
\text { of WRPC }\end{array}$ & Document of WRPC & Normative acts & $\begin{array}{l}\text { The essence } \\
\text { of the changes }\end{array}$ \\
\hline 1 & $\begin{array}{l}\text { Restrictions } \\
\text { on missionary } \\
\text { activity by } \\
\text { destructive } \\
\text { religious } \\
\text { associations }\end{array}$ & $\begin{array}{l}\text { Resolution of the } \\
\text { thematic group } \\
\text { "State development } \\
\text { of Russia" I WRPC; } \\
\text { Resolution of the } \\
\text { thematic group } \\
\text { "Ways and goals } \\
\text { of the spiritual revival } \\
\text { of Russia" I WRPC }\end{array}$ & $\begin{array}{l}\text { Federal Law of } \\
06.07 .2016 \text { No. } 374-F Z \\
\text { "On Amendments to the } \\
\text { Federal Law" on } \\
\text { Countering Terrorism } \\
\text { "and certain legislative } \\
\text { acts of the Russian } \\
\text { Federation in terms of } \\
\text { establishing additional } \\
\text { measures to counter } \\
\text { terrorism and ensure } \\
\text { public safety" }\end{array}$ & $\begin{array}{l}\text { The concept of } \\
\text { "missionary activity" } \\
\text { has been introduced } \\
\text { and a number of } \\
\text { restrictions have been } \\
\text { introduced for local } \\
\text { religious organizations } \\
\text { and religious groups, } \\
\text { concerning, } \\
\text { in particular, inviting } \\
\text { foreign citizens to } \\
\text { engage in preaching } \\
\text { and other religious } \\
\text { activities } \\
\end{array}$ \\
\hline 2 & $\begin{array}{l}\text { Return of } \\
\text { property seized } \\
\text { during } \\
\text { the Soviet era } \\
\text { back to religious } \\
\text { organizations }\end{array}$ & $\begin{array}{l}\text { III WRPC documents; } \\
\text { Resolution X WRPC } \\
\text { in support of the } \\
\text { transfer of buildings } \\
\text { in the Ryazan Kremlin } \\
\text { to the Church. Official } \\
\text { website of the World } \\
\text { Russian People's } \\
\text { Council } \\
\end{array}$ & $\begin{array}{l}\text { Federal Law of } \\
\text { November } 30,2010 \\
\text { No. } 327 \text { FZ } \\
\text { "On the Transfer of State } \\
\text { or Municipal Property } \\
\text { of Religious Purpose to } \\
\text { Religious Organizations" }\end{array}$ & $\begin{array}{l}\text { Religious organizations, } \\
\text { mainly the Russian } \\
\text { Orthodox Church, } \\
\text { received the ownership } \\
\text { (use) of property } \\
\text { nationalized by the } \\
\text { Soviet government }\end{array}$ \\
\hline \multirow{3}{*}{3} & \multirow{3}{*}{$\begin{array}{l}\text { Spiritual and } \\
\text { religious } \\
\text { education: } \\
\text { teaching in } \\
\text { schools } \\
\text { of the FOC, } \\
\text { the inclusion } \\
\text { of FRCSE in the } \\
\text { FES, certification } \\
\text { and accreditation } \\
\text { of theological } \\
\text { educational } \\
\text { institutions, } \\
\text { the inclusion } \\
\text { of "theology" } \\
\text { in the list } \\
\text { of scientific } \\
\text { specialties } \\
\text { of the Higher } \\
\text { Attestation } \\
\text { Commission }\end{array}$} & $\begin{array}{l}\text { Resolution VIII } \\
\text { of the WRPC on } \\
\text { spiritual and religious } \\
\text { education in Russia }\end{array}$ & $\begin{array}{l}\text { Order of the Ministry of } \\
\text { Education and Science } \\
\text { of } 01.02 .2012 \text { No. } 74 \\
\text { "On Amendments to the } \\
\text { Federal Basic } \\
\text { Curriculum and Model } \\
\text { Curricula for Educational } \\
\text { Institutions of the } \\
\text { Russian Federation } \\
\text { Implementing General } \\
\text { Education Programs" }\end{array}$ & $\begin{array}{l}\text { Into the basic } \\
\text { curriculum of primary } \\
\text { education (grade IV) } \\
\text { the subject } \\
\text { "Fundamentals } \\
\text { of Religious Cultures } \\
\text { and Secular Ethics" } \\
\text { was introduced } \\
\text { in the amount } \\
\text { of } 34 \text { hours per year }\end{array}$ \\
\hline & & \multirow{2}{*}{$\begin{array}{l}\text { Resolution } \\
\text { "On the development } \\
\text { of the national system } \\
\text { of religious education } \\
\text { and science" XI WRPC }\end{array}$} & $\begin{array}{l}\text { Federal Law No. 14-FZ } \\
\text { of February 28, 2008 } \\
\text { "On Amendments to } \\
\text { Certain Legislative Acts } \\
\text { of the Russian } \\
\text { Federation Regarding } \\
\text { Licensing and } \\
\text { Accreditation of } \\
\text { Professional Religious } \\
\text { Education Institutions } \\
\text { (Spiritual Educational } \\
\text { Institutions)" }\end{array}$ & $\begin{array}{l}\text { Religious universities } \\
\text { received the right } \\
\text { to issue state diplomas }\end{array}$ \\
\hline & & & $\begin{array}{l}\text { Minutes of the Presidium } \\
\text { of the Higher Attestation } \\
\text { Commission under the } \\
\text { Ministry of Education } \\
\text { and Science of the } \\
\text { Russian Federation No. } \\
24 \text { dated September } 25, \\
2015, \text { recommendation } \\
\text { No. } 24 / 555\end{array}$ & $\begin{array}{l}\text { "Theology" is included } \\
\text { in the list of scientific } \\
\text { specialties }\end{array}$ \\
\hline
\end{tabular}


The end of the table 1

\begin{tabular}{|c|c|c|c|c|}
\hline No. & $\begin{array}{c}\text { Ideas developed } \\
\text { within } \\
\text { the framework } \\
\text { of WRPC }\end{array}$ & Document of WRPC & Normative acts & $\begin{array}{l}\text { The essence } \\
\text { of the changes }\end{array}$ \\
\hline 4 & $\begin{array}{l}\text { Inadmissibility } \\
\text { of insulting } \\
\text { religious and } \\
\text { national feelings, } \\
\text { revered shrines }\end{array}$ & $\begin{array}{l}\text { Declaration of Human } \\
\text { Rights and Dignity, } \\
\text { adopted at the XWRPC }\end{array}$ & $\begin{array}{l}\text { Federal Law of June 29, } \\
2013 \mathrm{~N} 136-\mathrm{FZ} \text { "On } \\
\text { Amendments to Article } \\
148 \text { of the Criminal Code } \\
\text { of the Russian Federation } \\
\text { and Certain Legislative } \\
\text { Acts of the Russian } \\
\text { Federation in order to } \\
\text { counteract insult to the } \\
\text { religious beliefs and } \\
\text { feelings of citizens" }\end{array}$ & $\begin{array}{l}\text { Administrative } \\
\text { and criminal penalties } \\
\text { for public actions } \\
\text { expressing clear } \\
\text { disrespect for society } \\
\text { and committed in order } \\
\text { to offend the religious } \\
\text { feelings of believers are } \\
\text { introduced }\end{array}$ \\
\hline 5 & $\begin{array}{l}\text { The need to amend } \\
\text { the Russian } \\
\text { Constitution } \\
\text { on patriotic } \\
\text { education } \\
\text { of citizens and } \\
\text { on the protection } \\
\text { of historical truth }\end{array}$ & $\begin{array}{l}\text { Resolution } \\
\text { of the section } \\
\text { "History of Russia - } \\
\text { the history of the love } \\
\text { of the Fatherland. } \\
\text { Problems of patriotism } \\
\text { in modern Russia", } \\
\text { XVI WRPC }\end{array}$ & $\begin{array}{l}\text { Article } 67.1 \text { of the } \\
\text { Constitution of the } \\
\text { Russian Federation }\end{array}$ & $\begin{array}{l}\text { Provisions have been } \\
\text { made on honoring } \\
\text { the memory } \\
\text { of the defenders } \\
\text { of the Fatherland, } \\
\text { ensuring the protection } \\
\text { of historical truth, raising } \\
\text { patriotism in children }\end{array}$ \\
\hline
\end{tabular}

Source: made by the author.

Although there are no sufficient grounds for stating an unambiguous causal relationship between these two factors, we can confidently state a serious significance of the WRPC for the state and loyalty of the top state officials to a range of issues discussed at the Council. As noted by the mayor of Moscow Sobyanin S.S. in the address to the Council: "while discussing the problems of spiritual unity and diversity, the relationship between traditions and progress, you provide conclusions and recommendations that will certainly be in demand by the society and the state" 41 .

\section{Conclusion}

Therefore, the WRPC can reasonably be called one of the regulators of modern Russian politics, whose position the state treats with special attention. The interest of the authorities in the activities of the Council is due to the search for a value basis for the directions of social development and the desire to implement traditional spiritual and moral foundations into political and legal reality. Protecting traditional values, the state relies on the formation of the ideological attitudes of citizens, the harmonization and consolidation of society, as well as on ensuring religious security. In this context the reception of the WRPC documents, saturated with spiritual and moral ideals, occurs naturally and effortlessly. This is confirmed by the final words of greetings from the President of Russia Putin V.V. to the last Council that took place: "I want to emphasize that all your constructive proposals

\footnotetext{
${ }^{41}$ Speech by the Mayor of Moscow S.S. Sobyanin at XXII WRPC. The official website of the World Russian People's Council. URL: https:/vrns.ru/documents/vystuplenie-mera-moskvy-s-s-sobyanina/ (accessed: 15.05.2021).
} 
will certainly be in demand"42. Therefore, in general, the WRPC can be claimed to be one of the generators of political concepts of Orthodox identity and informal catalysts for reforming the Russian legal field.

Received / Поступила в редакцию: 10.06.2021 Accepted / Принята к публикации: 15.08.2021

\section{References / Библиографический список}

Bogachev, M.I. (2018). Continu abitur: Social and Religious Life of Russian Regions. State, Religion and Church in Russia and Worldwide, 3(36), 224-238.

Bogachev, M.I., \& Sorvin, K.V. (2020). Politics in the Church: For Whom Do Orthodox Priests Call to Vote? State, Religion and Church in Russia and Worldwide, (3), 331-361.

Ierusalimskiy, Yu.Yu., \& Rudakov, A.B. (2019). The role of the World Russian People's Council in the consolidation of Russian society in the 1990s. House of the Romanovs and the Yaroslavl region: conference proceeding (pp. 437-444). Yaroslavl: Indigo. (In Russian).

Иерусалимский Ю.Ю., Рудаков А.Б. Роль Всемирного русского народного собора в консолидации российского общества в 1990-х годах // Международная научно-практическая конференция «Дом Романовых и Ярославский край»: материалы конференции / под ред. Ю.Ю. Иерусалимского. Ярославль: Индиго, 2019. С. 437-444.

Ierusalimskiy, Yu.Yu., \& Rudakov, A.B. (2021). Issues of education, science and culture in the work of the World Russian People's Council at the end of the twentieth century. Bulletin of Moscow Region State University. History and Political Science, (2), 117-124. (In Russian).

Иерусалимский Ю.Ю., Рудаков А.Б. Вопросы образования, науки и культуры в деятельности Всемирного русского народного собора в конце XX столетия // Вестник Московского государственного областного университета. Серия: История и политические науки. 2021. № 2. C. 117-124. DOI: 10.18384/2310-676X-2021-2-117-124

Meshcheryakova, A.F. (2020). State-church interaction as a factor in the formation of a secular state and civil society in Russia. Electronic scientific journal "Science. Society. State", 8(1), 27-36. Retrieved from http://esj.pnzgu.ru (In Russian).

Мещерякова А.Ф. Государственно-церковное взаимодействие как фактор формирования светского государства и гражданского общества в России // Электронный научный журнал «Наука. Общество. Государство». 2020. Т. 8. № 1 (29). С. 27-36. URL: http://esj.pnzgu.ru (дата обращения: 21.09.2021). DOI: 10.21685/2307-9525-2020-8-1-4

Mchedlova, M.M. (2020). Metaphysics of russian society: ideological constructions, institutional configurations and contemporary cognitive shift. Pushkin Leningrad State University Journal, (3), 59-79. (In Russian).

Мчедлова M.M. Метафизика российского общества: идейные конструкции, институциональные конфигурации и современные познавательные сдвиги // Вестник Ленинградского государственного университета имени А.С. Пушкина. 2020. № 3. С. 59-79.

Mchedlova, M.M. (2020). Religion in Political Construction of Modernity: Editorial Introduction. RUDN Journal of Political Science, 22(4), 541-546. (In Russian).

Мчедлова M.M. Религия в политических конструкциях современности: представляю номер // Вестник Российского университета дружбы народов. Серия: Политология. 2020. T. 22. № 4. C. 541-546. DOI: 10.22363/2313-1438-2020-22-4-541-546

Mchedlova, M.M., \& Kazarinova D.B. (2020). The identity politics: competition of new theoretical meanings and political strategies. Political Science, (4), 13-35. (In Russian).

\footnotetext{
${ }^{42}$ Greetings from the President of the Russian Federation V.V. Putin to XXIII WRPC. The official website of the World Russian People's Council. URL: https://vrns.ru/documents/privetstvieprezidenta-rf-v-v-putina/ (accessed: 21.09.2021).
} 
Мчедлова М.М., Казаринова Д.Б. Политика идентичности: конкуренция новых теоретических смыслов и политических стратегий // Политическая наука. 2020. № 4. С. 13-35. DOI: http://www.doi.org/10.31249/poln/2020.04.01

Mchedlova, M.M., \& Kofanova, E.N. (2020). Russia in Anticipation of Changes: Religious Factor and Socio-political Preferences. RUDN Journal of Political Science, 22(1), 7-21. (In Russian). Мчедлова М.M., Кофанова E.Н. Россия в ожидании перемен: религиозный фактор и социально-политические предпочтения // Вестник Российского университета дружбы народов. Серия: Политология. 2020. Т. 22. № 1. С. 7-21. DOI: 10.22363/2313-1438-202022-1-7-21

Pinkevich, V.K. (2020). The Politicization of Society and the Religious Issues in Modern Russia. RUDN Journal of Political Science, 22(4), 647-663. (In Russian).

Пинкевич B.K. Политизация общества и религиозные отношения в современной России // Вестник Российского университета дружбы народов. Серия: Политология. 2020. Т. 22. № 4. C. 647-663. DOI: 10.22363/2313-1438-2020-22-4-647-663

Rudakov, A.B. (2020). Issues of demography and health in the perception of the participants of the IV World Russian National Council (1997). Modern science: actual problems of theory and practice. Humanities, (6-2), 19-22. (In Russian).

Рудаков А.Б. Вопросы демографии и здравоохранения в восприятии участников IV Bceмирного русского народного собора (1997 г.) // Современная наука: актуальные проблемы теории и практики. Серия: Гуманитарные науки. 2020. № 6-2. С. 19-22.

Shchipkov, A.V. (2018). Questions of ideology. Moscow: Abris. (In Russian). Щипков А.В. Вопросы идеологии: монография. М.: Абрис, 2018.

Shchipkov, A.V. (2021). Discourse of Orthodoxy. Description of the ideological space of modern Russian Orthodoxy. Moscow: Moscow Patriarchate of the Russian Orthodox Church publ. (In Russian).

Щипков А. В. Дискурс ортодоксии. Описание идейного пространства современного русского православия. М.: Издательство Московской Патриархии Русской Православной Церкви, 2021.

\section{About the author:}

Natalya D. Shikher - postgraduate student of the Department of National and Federal Relations, RANEPA, Head of the Department of the Office of the Commissioner for Human Rights in the Russian Federation (e-mail: raspberry33@yandex.ru) (ORCID: 0000-0002-0141-3814)

\section{Сведения об авторе:}

Шихер Наталья Дмитриевна - аспирант кафедры национальных и федеративных отношений РАНХиГС, начальник отдела защиты политических прав Аппарата Уполномоченного по правам человека в Российской Федерации (e-mail: raspberry33@yandex.ru) (ORCID: 0000-00020141-3814) 